\title{
PELOKALAN HAK ASASI MANUSIA MELALUI PARTISIPASI PUBLIK DALAM KEBIJAKAN BERBASIS HAK ASASI MANUSIA ${ }^{1}$ (Localizing Human Rights by Public Participation in Human Rights-Based Policies)
}

\author{
Sabrina Nadilla \\ Pusat Penelitian dan Pengembangan Hak Asasi Manusia \\ Badan Penelitian dan Pengembangan Hukum dan HAM \\ Kementerian Hukum dan Hak Asasi Manusia Republik Indonesia \\ Jalan H.R. Rasuna Said Kav. 4-5, Jakarta Selatan \\ Telp.021-2525015 \\ sabrina@balitbangham.go.id
}

Tulisan Diterima: 17-05-2019; Direvisi: 14-06-2019; Disetujui Diterbitkan: 23-05-2019

DOI: http://dx.doi.org/10.30641/ham.2019.10.85-98

\begin{abstract}
Efforts had been made to take Human Rights values down to the local levels since the 1990s, by means of many concepts, one of which is the adoption of human rights policies at the city level. The concept has challenged the approach that all this time centers only around the state and opened more spaces for the ideas that the implementation of human rights values should be a concern of all government levels, not limited only to the central government as it is today. In the context of Indonesia, the efforts in localizing the human rights values have been made by means of some pro-human rights policies. These include the awards for the district/city that have demonstrated their care to human rights values, which awards among other are granted by the Ministry of Law and Human Rights, and the Bandung City Human Rights project. This study uses a qualitative approach based on case studies. Analysis is made by applying the concept of human rights-based approach in human rights policies. In the human rights localization perspective, human rights policies in the city of Bandung have shown some indications. Firstly, the Bandung Declaration of Human Rights, that should have been considered as a bottom-up human rights-based policy, has not been able to support the efforts to localize the human rights values in the city of Bandung. Secondly, the Human Rights Cities Award as a top-down policy, despite of gaining some positive responses from the government and vertical governmental agencies that form parts of the policies' implementer, has failed to secure adequate legitimacy from the citizen of Bandung.
\end{abstract}

Keywords: human rights localization; human rights-based policies; public participation.

\begin{abstract}
ABSTRAK
Upaya untuk membawa nilai-nilai Hak Asasi Manusia (HAM) ke tingkat lokal sudah mencuat sejak 1990-an, melalui berbagai konsep, salah satunya human rights in the city. Konsep tersebut menantang pendekatan HAM yang selama ini hanya terpusat pada negara, sehingga membuka ruang bagi ide bahwa implementasi nilainilai HAM harus ditangani oleh berbagai tingkatan pemerintahan, bukan lagi terbatas pada pemerintah pusat. Dalam konteks Indonesia, upaya melokalkan nilai-nilai HAM telah dilakukan melalui berbagai kebijakan hak asasi manusia. Kebijakan tersebut antara lain penghargaan kabupaten/kota peduli HAM yang diselenggarakan oleh Kementerian Hukum dan Hak Asasi Manusia, dan proyek Kota HAM Bandung. Kajian ini menggunakan pendekatan kualitatif yang berbasis pada studi kasus, analisis dilakukan dengan menerapkan konsep pendekatan hak asasi manusia (human rights-based approach) dalam kebijakan hak asasi manusia. Dalam perspektif pelokalan hak asasi manusia, kebijakan HAM di Kota Bandung menunjukkan beberapa indikasi. Pertama, kebijakan Deklarasi HAM Bandung sebagai suatu kebijakan berbasis hak asasi manusia yang bersifat bottomup masih belum mampu mendukung upaya pelokalan HAM di kota Bandung. Kedua, kebijakan Penghargaan
\end{abstract}

$1 \quad$ Penelitian ini merupakan bagian tidak terpisahkan dari Laporan Hasil Penelitian "Institusionalisasi Hak Asasi Manusia di Tingkat Daerah Melalui Penghargaan Kabupaten/Kota Peduli Hak Asasi Manusia” 
Kabupaten/Kota Peduli HAM sebagai suatu kebijakan yang bersifat top-down, meskipun mendapatkan respons positif dari pemerintah kota dan instansi vertikal sebagai bagian dari pelaksana kebijakan, tidak mendapatkan legitimasi yang cukup dari masyarakat kota Bandung.

Kata Kunci: pelokalan HAM; kebijakan berbasis HAM; partisipasi publik.

\section{PENDAHULUAN}

Menurut tradisi positivisme hukum, negara merupakan satu-satunya sumber hak-hak kewarganegaraan yang sah, namun faktanya, kewarganegaraan tidak hanya ditetapkan secara de jure oleh negara, namun juga de facto melalui interaksi antaraktor komunitas yang terjadi dalam lingkup urban. ${ }^{2}$ Sejalan dengan tradisi tersebut, menurut hukum internasional, hanya negara sebagai suatu entitas utuh yang dapat menjadi pihak dalam suatu perjanjian internasional. Sebagai implikasi dari tindakan ratifikasi dan aksesi terhadap konvensi internasional tentang hak asasi manusia, negara merupakan satu-satunya pihak yang memiliki tanggungjawab untuk melakukan penghormatan, pelindungan, dan pemenuhan terhadap HAM. Lebih jauh, suatu negara yang terlibat sebagai pihak dalam international human rights complaint mechanism tidak dapat melakukan pembelaan dengan menyatakan bahwa dugaan pelanggaran hak asasi manusia dilakukan oleh pemerintah daerah, bukan pemerintah pusat. ${ }^{3}$ Pasal 27 Vienna Convention on the Law of Treaties (VCLT) 1969 menegaskan bahwa a party may not invoke the provisions of its internal law as justification for its failure to perform a treaty, sehingga kegagalan otoritas publik termasuk pemerintah daerah dalam memenuhi kewajiban hak asasi manusia, harus dipertanggungjawabkan oleh negara.

Upaya untuk membawa nilai-nilai hak asasi manusia ke tingkat lokal sudah mencuat sejak 1990-an, salah satunya melalui konsep human rights in the cities yang berkembang sejak diluncurkannya European Charter for the Safeguarding of Human Rights in the City $(E C H R C) .{ }^{4}$ Konsep ini menantang pendekatan

2 Eva Garcia Chueca, "Human Rights in the City and the Right to the City," in Global Urban Justice: The Rise of Human Rights Cities, ed. Barbara Oomen, Martha F. Davis, and Michele Grigolo (Cambridge University Press, 2016), 103-120.

3 Human Rights Council, "Role of Local Government in the Promotion and Protection of Human Rights," vol. A/ $\mathrm{HRC} / 30 / 4,2015$.

4 European Charter for Safeguarding Human Rights in the
HAM yang selama ini hanya terpusat pada negara, sehingga membuka ruang bagi ide bahwa implementasi nilai-nilai HAM harus ditangani oleh berbagai tingkatan pemerintahan, bukan lagi terbatas pada pemerintah pusat. ${ }^{5}$ Permasalahan hak asasi manusia umumnya berkembang di tingkat lokal, namun pada tingkat lokal pula permasalahan tersebut dapat diselesaikan dengan efektif, karena kondisi hak asasi manusia masyarakat dapat benarbenar dipantau dari jarak dekat. Pada tingkatan ini, partisipasi masyarakat dapat disasar untuk menyelesaikan permasalahan yang ada, termasuk salah satunya melalui pembentukan kebijakan yang diperlukan. ${ }^{6}$ Sehingga, kota muncul sebagai organ utama dalam memastikan pelindungan dan pengembangan hak asasi manusia, tugas yang selama ini sering terabaikan oleh pemerintah pusat.

Salah satu praktik terbaik dari konsep human rights in the city adalah Barcelona, kota pertama yang sukses mengadopsi ECHRC ke dalam peraturan lokal. Berangkat dari masalah migrasi dan meningkatnya keberagaman ras, etnis, dan agama, Barcelona mendirikan Civil Rights Department $(C R D)$ yang berfungsi menyediakan pelayanan hukum bagi orang-orang yang mengalami diskriminasi. ${ }^{7}$ Selain $C R D$, Barcelona juga mendirikan Oficina per la No Discriminació (Kantor Non Diskriminasi) yang secara khusus memberi perhatian pada diskriminasi terhadap kelompok rentan: minoritas seksual, minoritas agama, emigran, difabel, ODHA, anak, dan kaum muda. ${ }^{8}$ Pada tingkat Asia, Kota Gwangju di Korea Selatan juga menjadi salah satu role model kota HAM dunia. Inisiasi Kota HAM Gwangju merupakan warisan dari May 18th Gwangju Democratization Movement, suatu gerakan

City (Saint Denis, 2002).

5 Chueca, "Human Rights in the City and the Right to the City."

6 OHCHR, "Achievements and Challenges of the Human Rights City Gwangju” 1929 (2011).

7 INFID, Kertas Kertas Kebijakan: Kabupaten/Kota HAM Sebagai Strategi Pelaksanaan Hak Asasi Manusia Di Daerah Dan Peran Pemerintah Pusat (Jakarta, n.d.).

8 INFID, Buku Panduan Kabupaten/Kota HAM, 3rd ed., vol. 3 (Jakarta: INFID, 2018). 
perlawanan rakyat kota terhadap kekerasan pemerintah untuk melindungi demokrasi dan martabat kemanusiaan. Momen bersejarah tersebut melatarbelakangi rakyat kota Gwangju untuk mengabadikan semangat pergerakan dalam bentuk kota HAM. ${ }^{9}$ Melalui Human Rights Improvement and Democratization, Human Rights, and Peace City Promotion Ordinance yang disahkan pada 2007, Gwangju menegaskan kewajiban kota untuk memajukan hak asasi manusia warganya, di antaranya pembentukan master plan (rencana induk) pembangunan HAM, pembentukan Piagam HAM Gwangju yang memuat indikator HAM, serta sistem pendidikan hak asasi manusia. ${ }^{10}$ Piagam HAM Gwangju, dalam pembentukannya, melibatkan aktivis organisasi non-pemerintah, akademisi, ahli, pejabat publik, hingga aparat di instansi terkait. Bahkan, untuk mengumpulkan opini beragam terkait hak-hak kelompok khusus, hingga seribu tiga ratus organisasi masyarakat sipil di bidang anak, lansia, difabel, perempuan dan pekerja migran ikut andil dalam pembentukan piagam. ${ }^{11}$

Dalam konteks Indonesia, upaya pelokalan nilai-nilai hak asasi manusia telah dilakukan melalui berbagai kebijakan hak asasi manusia. Kebijakan tersebut antara lain penghargaan kabupaten/kota peduli HAM yang diselenggarakan oleh Kementerian Hukum dan Hak Asasi Manusia, dan proyek Kota HAM Bandung yang diinisiasi Walikota Ridwan Kamil bekerjasama dengan Foundation for International Human Rights Reporting Standards (FIHRSST). Sejak awal penyelenggaraan penghargaan kabupaten/ kota peduli HAM pada 2015 lalu, Bandung menjadi salah satu kota yang rutin menerima predikat kota peduli HAM. Sejalan dengan prestasi tersebut, Bandung juga mendeklarasikan diri sebagai Kota HAM pertama di Indonesia. ${ }^{12}$ Melalui deklarasi tersebut, Bandung berusaha bertransformasi menjadi kota yang berkomitmen untuk mewujudkan pemenuhan hak asasi manusia

9 OHCHR, "Achievements and Challenges of the Human Rights City Gwangju."

10 INFID, Kertas Kertas Kebijakan: Kabupaten/Kota HAM Sebagai Strategi Pelaksanaan Hak Asasi Manusia Di Daerah Dan Peran Pemerintah Pusat.

11 OHCHR, "Achievements and Challenges of the Human Rights City Gwangju."

12 Afif Permana, "Jadi Kota HAM Pertama Di Indonesia, Bandung Ingin Kota Lain Ikut," last modified 2015, accessed May 7, 2019, http://bandung.bisnis.com/ $\mathrm{read} / 20150424 / 82444 / 532261 /$ jadi-kota-ham-pertama-diindonesia-bandung-ingin-kota-lain-ikut. bagi seluruh warganya. ${ }^{13}$

Kendati demikian, temuan lapangan menunjukkan adanya distorsi antara kebijakan yang diambil pemerintah dengan harapan warga kota Bandung. Distorsi ini muncul dalam bentuk beragam, dari aksi penolakan, topik pengaduan yang sama tiap tahunnya, hingga munculnya kasus-kasus dugaan pelanggaran hak asasi manusia. Salah satunya dalam konteks ruang publik, pembangunan mall dan hotel di lahan eks Plaza Palaguna kembali menjadi preseden buruk dalam pemenuhan HAM di kota Bandung. Sebagai bentuk protes atas rencana pembangunan tersebut, sebanyak 100 seniman dan 41 komunitas menggelar aksi kebudayaan dengan tajuk \#saveXpalaguna. Aksi kebudayaan ini melibatkan kalangan seniman, budayawan, aktivis lingkungan, pencinta alam, guru, pelajar, pemuda, agamawan, perempuan, dan warga kota lainnya. ${ }^{14}$

Berdasarkan latar belakang tersebut, permasalahan yang dapat diidentifikasi ialah adanya ketidaksinkronan antara kebijakan hak asasi manusia pemerintah dengan permasalahan HAM di masyarakat, yang pada tingkatan tertentu dapat menghambat upaya pelokalan nilai-nilai HAM ke level kota. Ketidaksinkronan ini, salah satunya, disebabkan oleh kegagalan pemerintah dalam melihat problematika di lapangan, seperti isu HAM prioritas dan karakteristik lokal daerah. Lebih lanjut, rumusan masalah dari kajian ini adalah, bagaimana relasi antara pembentukan kebijakan berbasis hak asasi manusia (human rights-based approach) dengan upaya pelokalan nilai-nilai hak asasi manusia ke level daerah? Sehingga, tujuan dari kajian ini yakni untuk mengetahui relasi antara pembentukan kebijakan berbasis hak asasi manusia dengan keberhasilan upaya pelokalan nilai-nilai hak asasi manusia ke level daerah.

13 FIHRRST, "Making the Right Start - Bandung Begins Its Journey as Our Human Rights City," last modified 2015, accessed May 8, 2019, http://www.fihrrst.org/making-theright-start-bandung-begins-its-journey-as-our-humanrights-city.

14 Widi Hatmoko, "\#SaveXpalaguna: Seniman Tolak Bekas Gedung Palaguna Jadi Mal Dan Hotel," Merahputih.Com, accessed May 8, 2019, https://merahputih.com/post/read/ savexpalaguna-seniman-tolak-bekas-gedung-palagunajadi-mal-dan-hotel. 


\section{METODE PENELITIAN}

Kajian ini menggunakan pendekatan kualitatif yang berbasis pada studi kasus. Studi kasus digunakan untuk memastikan permasalahan tidak hanya dilihat melalui satu lensa saja, namun melalui beragam lensa yang dapat mengungkap dan memahami suatu fenomena dari berbagai aspek. ${ }^{15}$ Dengan melihat upaya pelokalan hak asasi manusia di kota Bandung, analisis dilakukan dengan menerapkan konsep pendekatan berbasis hak asasi manusia (human rights-based approach) dalam kebijakan hak asasi manusia.

Dalam pendekatan kualitatif, pengumpulan data dilakukan melalui open-ended interview terhadap informan yang terlibat langsung dalam proses pembentukan kebijakan hak asasi manusia di kota Bandung, dalam hal ini bagian hukum dan hak asasi manusia pemerintah kota Bandung. Untuk mengetahui respons masyarakat terhadap kebijakan hak asasi manusia, wawancara juga dilakukan terhadap akademisi dan Lembaga Bantuan Hukum (LBH) Bandung. Selanjutnya, untuk melengkapi data hasil wawancara, dilakukan studi dokumen melalui pengumpulan dokumen hak asasi manusia kota Bandung, regulasi hak asasi manusia nasional dan internasional, karya tulis ilmiah, serta laporan instansi pemerintah maupun organisasi internasional.

\section{PEMBAHASAN}

\section{A. Localizing Human Rights: Upaya Melokal- kan Nilai-Nilai Global}

Globalisasi ekonomi sebagai proses yang menembus batasan antar negara dalam pertukaran uang, barang, produksi, dan tenaga kerja, memengaruhi hak asasi manusia. Dari perspektif hak asasi manusia, globalisasi ekonomi menimbulkan urgensi untuk mengkaji kembali peran dan tanggungjawab negara selaku pengemban tugas utama dalam hak asasi manusia dalam ekonomi global maupun domestik. ${ }^{16}$ Menurut De Feyter, lokalisasi hak asasi manusia adalah

15 Pamela Baxter and Susan Jack, "The Qualitative Report Qualitative Case Study Methodology: Study Design and Implementation for Novice Researchers," The qualitative reportualitative report 13, no. 2 (2008): 544-559.

16 Koen De Feyter, Localizing Human Rights (Antwerp, 2006). taking the human rights needs as formulated by local people (in response to the impact of economic globalization on their lives) as the starting point both for the further interpretation and elaboration of human rights norms, and for the development of human rights action, at all levels ranging from the domestic to the global. ${ }^{17}$

De Feyter beranggapan bahwa agar hak asasi manusia dapat diterima oleh seluruh masyarakat, maka diperlukan hak asasi manusia yang spesifik, sehingga harus dilakukan upaya pelokalan nilainilai tersebut sesuai dengan konteks daerah. Dalam rangka menghadapi tantangan globalisasi ekonomi tersebut, yang merupakan proses top down, pengembangan hak asasi manusia perlu disesuaikan dengan kebutuhan hak asasi manusia yang didefinisikan oleh kelompok-kelompok lokal. ${ }^{18}$ Lokalisasi HAM merupakan suatu proses mengadopsi ide-ide global ke dalam instrumen hukum lokal ${ }^{19}$, dan bagaimana klaim hak asasi manusia lokal dapat memengaruhi pembentukan -jika tidak ditransformasikan menjadi- norma global. ${ }^{20}$

\section{Gambar 1}

Proses Lokalisasi Hak Asasi Manusia

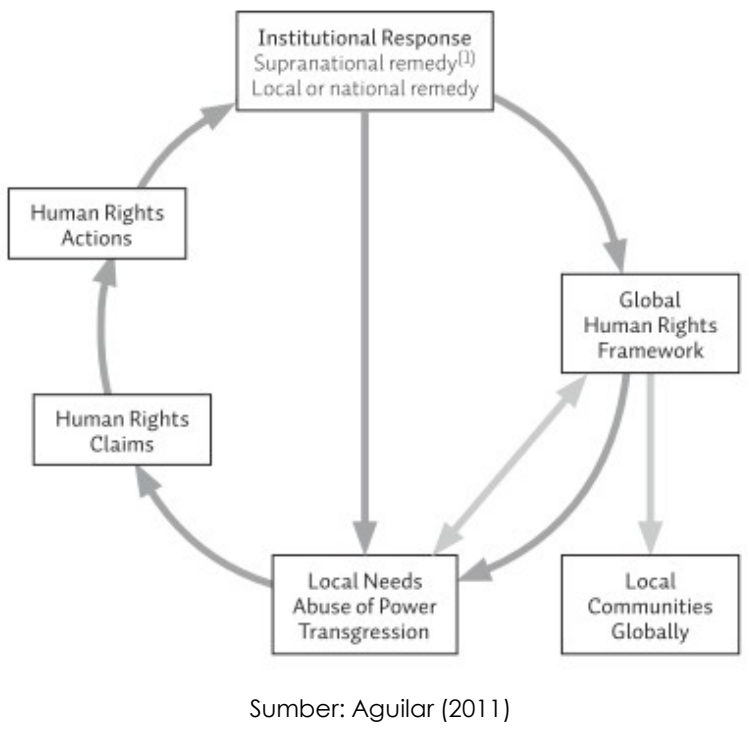

Aguilar menggambarkan lokalisasi HAM sebagai 'two ways highway', yakni dari global ke lokal dan lokal ke gobal. Secara lebih spesifik,

\footnotetext{
17 Ibid.

18 Arne Vandenbogaerde, "Localizing the Human Rights Council: A Case Study of the Declaration on the Rights of Peasants," Journal of Human Rights 16, no. 2 (2017): 220-241.

19 Ranita Ray, "Challenges in Localizing Global Human Rights," Societies Without Borders 7, no. 1 (2012): 29-51.

20 Vandenbogaerde, "Localizing the Human Rights Council: A Case Study of the Declaration on the Rights of Peasants."
} 
Aguilar menjelaskan proses lokalisasi $\mathrm{HAM}^{21}$ dalam lintasan pertama, pengalaman masyarakat lokal atas ketidakberdayaan menjadi awal bagi jaringan antar aktor (termasuk komunitas lokal) yang dalam lintasan kedua, menggunakan kerangka kerja hak asasi manusia global untuk membuat tuntutan terkait hak asasi manusia pada berbagai tingkatan dan ruang politik. Tindakan tersebut dalam lintasan ketiga, ditargetkan kepada respons institusional melalui efektivitas dan relevansi respons terhadap hak asasi manusia diuji. Dalam lintasan keempat, lokalisasi juga mensyaratkan adanya penerjemahan respons institusional ke dalam interpretasi standar hak asasi manusia secara lebih lanjut. Pada akhirnya dalam lintasan kelima, kelompok masyarakat lokal menjadi sumber untuk meningkatkan pelindungan hak asasi manusia, baik di kelompok tersebut maupun kelompok masyarakat lokal lainnya.

Melalui lintasan tersebut, dapat dilakukan identifikasi terhadap aktor-aktor yang terlibat dalam proses pelokalan hak asasi manusia, yang keberhasilannya, tergantung kepada kerjasama yang baik antaraktor dalam berbagai tingkatan. Terdapat empat mata rantai aktor yang dapat diidentifikasi. ${ }^{22}$ Aktor pertama adalah komunitas masyarakat lokal, aktor ini sangat penting dalam melakukan identifikasi atas kebutuhan hak asasi manusia di tingkat lokal. Aktor selanjutnya adalah organisasi non-pemerintah (NGO) di bidang hak asasi manusia. NGO mengambil peran dengan mendampingi komunitas masyarakat lokal dalam mengenalkan pendekatan berbasis hak (rightsbased approaches) serta kemudian mendukung masyarakat untuk membawa agenda hak asasi manusia ke tingkat nasional hingga lebih jauh. NGO lokal juga berperan sebagai jejaring koneksi dengan organisasi masyarakat sipil di tingkat internasional. NGO internasional menjadi penting karena dalam konteks globalisasi ekonomi, faktor penyebab pelanggaran hak asasi manusia tidak hanya ditemukan pada tingkat nasional. Terakhir, perlu dibangun kolaborasi antara ketiga aktor di atas sebagai representasi dari masyarakat dengan pemerintah selaku pembentuk kebijakan dan otoritas penegak hukum. Sehingga, kebutuhan hak

\footnotetext{
21 Gaby Oré Aguilar, "The Local Relevance of Human Rights:A Methodological Approach," The Local Relevance of Hu- man Rights (2011): 109-146.

22 Feyter, Localizing Human Rights.
}

asasi manusia di tingkat lokal dapat diakomodasi melalui pembentukan kebijakan yang tepat sasaran.

Teridentifikasinya proses pelokalan hak asasi manusia beserta aktor-aktor yang terlibat, maka dapat digambarkan bahwa untuk dapat terjadinya proses pelokalan tersebut, dibutuhkan kerjasama yang baik antara aktor masyarakat dengan pemerintah. Proses tersebut merupakan kolaborasi antardua aktor utama: masyarakat yang aktif dalam menyuarakan klaim atas hak-hak yang dimiliki, dan pemerintah yang membentuk kebijakan berdasarkan klaim hak asasi manusia dari masyarakat.

\section{B. Belajar dari Bandung: Mempersempit Kesenjangan melalui Partisipasi Publik dalam Pembentukan Kebijakan Hak Asasi Manusia}

Pemerintah kota Bandung sukses menjadi langganan penerima penghargaan kabupaten/ kota peduli HAM dari Kementerian Hukum dan HAM sejak awal diselenggarakan pada 2016 lalu. Kinerja pemerintah kota Bandung dalam penghormatan, pelindungan, pemenuhan, penegakan, dan pemajuan HAM dianggap telah memenuhi kriteria kota Peduli HAM, sebagaimana tercantum dalam Peraturan Menteri Hukum dan HAM (Permenkumham) Nomor 34 Tahun 2016. Kriteria tersebut didasarkan pada terpenuhinya tujuh hak, yakni: (a) hak atas kesehatan; (b) hak atas pendidikan; (c) hak perempuan dan anak; (d) hak atas kependudukan; (e) hak atas pekerjaan, (f) hak atas perumahan yang layak; dan (g) hak atas lingkungan yang berkelanjutan. ${ }^{23}$

Temuan lapangan menunjukkan bahwa tingkat keberterimaan (legitimasi) warga kota Bandung terhadap keberhasilan Bandung di penghargaan kabupaten/kota peduli HAM terbilang rendah. Salah satu penyebab rendahnya legitimasi warga adalah mengenai kriteria penghargaan yang tidak berhasil mengakomodasi harapan warga Bandung terhadap pemenuhan hak asasi manusia, mengingat selama ini pelanggaran yang terjadi ada di ranah hak sipil dan politik. Menurut informan,

“...Prinsipnya HAM itu tidak bisa dipilah dan tidak bisa dibagi ya. [...] Misalnya ekosob tentang pendidikan, di Indonesia pendidikan

23 Pasal 3 Permenkumham 34/2016 tentang Kriteria Kabupaten/Kota Peduli Hak Asasi Manusia 
perlu, negara perlu memfasilitasi itu. Saya rasa kriteria itu perlu dipertimbangkan, dalam konteks HAM, satu dan lainnya berkaitan dan tidak bisa dibagi. Di satu sisi bicara hak sipil politik, pasti berkaitan dengan hak ekosob. Kalau ukurannya sebatas hak ekosob, kalau Bandung secara ekosob memang terpenuhi, tapi sipil politiknya tidak, apakah layak menerima penghargaan itu. Kecuali kalau modelnya hanya tahapan, misalkan dari 10 titik, Kota Bandung sudah berada di titik mana, di titik 2 misalnya. [...] Karena publik itu menilai, akan berbeda apa yang dirasakan. [...] Kalau bentuknya penghargaan ini, pemda menerima penghargaan tentu senang, tapi dari masyarakat belum tentu, karena masih banyak pelanggaran. ${ }^{24}$

Dalam kesempatan lainnya, salah satu informan memberikan pandangannya mengenai kebijakan penghargaan kabupaten/kota peduli HAM dengan kriteria yang ditetapkan secara topdown melalui pusat. Pada umumnya, Bandung sebagai penerima penghargaan kota peduli HAM sudah baik, mengingat kriteria penghargaan sudah ditentukan dari pusat, sehingga bukan hal sulit bagi pemkot Bandung untuk mendapatkan penghargaan tersebut. Namun, dikhawatirkan ada reduksi terhadap substansi hak asasi manusia karena hal-hal yang bersifat formal dan administratif sebagaimana kriteria penghargaan yang sudah ditetapkan sebelumnya dari pemerintah pusat. ${ }^{25}$ Senada dengan informan sebelumnya, informan lain berpendapat

"Frankly to say, Jabar ini banyak mendapat penghargaan, tapi apa bisa dirasakan oleh rakyat? Karena semua berbasis portofolio, jadi penghargaan itu tidak menetes ke rakyatnya.,26

Di sisi lain, berdasarkan hasil wawancara dengan informan dari Kantor Wilayah Kementerian Hukum dan HAM Jawa Barat dan Pemerintah Kota Bandung, antusiasme aparat pemerintah dalam pelaksanaan program penghargaan kabupaten/ kota peduli HAM terbilang tinggi

“...Untuk Kota Bandung, [pemerintah kota, pen.] sangat aktif. Kita sempat dimintakan rapat koordinasi, dan kami pun mendorong OPD [Organisasi Perangkat Daerah-red] yang ada di Kota Bandung untuk mengumpulkan data. Akhirnya selesai tepat waktu. Cuma ada kebiasaan-kebiasaan kab/kota lain yang mengumpulkan dokumen yang sangat banyak, demi kelengkapan dokumen. Kota Bandung

24 Hasil Wawancara dengan Willy Hanafi, Lembaga Bantuan Hukum (LBH) Bandung, Bandung 6 Februari 2019

25 Hasil Wawancara dengan Epin Saepudin, Bandung, 6 Februari 2019

26 Hasil Wawancara dengan Susi Dwi Harijanti, Paguyuban Hak Asasi Manusia Universitas Padjadjaran, Bandung 6 Februari 2019 tidak ada masalah untuk pelaporan. Kalau untuk pendekatan OPD sendiri, karena OPD tidak mengurus HAM secara langsung [...] Khusus $\mathrm{Kab} /$ Kota kami sering menjadi narasumber, baik untuk kegiatan diseminasi, rapat koordinasi, atau penyusunan KKP dan aksi HAM. Tapi memang tidak semua mengundang kita, mungkin karena teknis tidak ada anggaran." 27

Kasubbag Hukum dan HAM pemerintah kota Bandung menuturkan

“.... kita selalu melakukan koordinasi lah dengan OPD, koordinasi tentang apa yang harus disiapkan lah oleh kita, meskipun tidak diminta pun itu harus ada di OPD itu. [...] kami juga menekankan, nanti kan laporan B4 dimulai, nanti kita saling mengingatkan kalo ini kewajiban kita [...] Kan kami juga melaporkan kepada beliau [Walikota, pen.] apabila ada perubahan dan kewajiban yang belum dipenuhi yang ada di nilai, pendidikan sekian, pekerjaan sekian, memang dilaporkan kepada beliau." 28

Sebelum mendulang prestasi pada penghargaan kabupaten/kota peduli HAM, Bandung terlebih dahulu menggelar Deklarasi HAM Bandung. Melalui deklarasi yang diinisiasi langsung oleh Walikota Ridwan Kamil, pemerintah kota Bandung berusaha bertransformasi menjadi kota yang berkomitmen untuk mewujudkan pemenuhan HAM bagi seluruh warganya. ${ }^{29}$ Sebagai tindak lanjut dari deklarasi, dilakukan sejumlah kegiatan sosialisasi dan interaksi dengan publik, seperti rangkaian diskusi kelompok terfokus (FGD), laman khusus dan komunikasi multimedia alternatif, maupun media lainnya. ${ }^{30}$ Rangkaian kegiatan sosialisasi melibatkan 150 stakeholders sebagai representasi dari warga kota Bandung, mulai dari komunitas, akademisi, organisasi masyarakat sipil, pemuka agama, kepolisian, militer, dan praktisi HAM, serta entitas bisnis dan Badan Usaha Milik Daerah (BUMD). Kegiatan tersebut bermaksud untuk mengumpulkan ide dan aspirasi mengenai hak apa saja yang akan dimasukkan ke dalam Piagam Kota HAM Bandung. Menurut informan,

27 Hasil Wawancara dengan Dani Kusmawan, Kantor Wilayah Kementerian Hukum dan HAM Jawa Barat, Bandung, 4 Februari 2019

28 Hasil Wawancara dengan Oca, Kasubbag Hukum dan HAM Pemerintah Kota Bandung, Bandung 6 Februari 2019

29 FIHRRST, "Making the Right Start - Bandung Begins Its Journey as Our Human Rights City."

30 Marzuki Darusman, "Bandung' ${ }^{\mathrm{TM}}$ s Efforts and Social Justice," The Jakarta Post, last modified 2015, accessed May 8, 2019, https://www.thejakartapost.com/news/2015/o4/23/ bandung-s-efforts-and-social-justice.html. 
"...Ada tiga isu utama yang dibahas pertama ialah hak-hak apa saja yang penting bagi warga bandung. Hak asasi manusia itu banyak, tapi buat orang bandung di antara yang banyak itu apa yang paling penting dan paling relevan. [...] Isu kedua, bagaimana hak-hak tersebut diterapkan atau diimplementasikan. Isu ketiga, bagaimana hak- hak itu dapat digugat apabila ada pelanggaran. Itu tiga pertanyaan utama yang kita berikan pada FGD pertama. Masing-masing kelompok ngomong. Dari hasil FGD pertama itu adalah masyarakat. FGD kedua itu dinas-dinas. FGD ketiga itu baru kita paparkan hasil FGD kesatu dan kedua dan bagaimana tanggapannya..."

Keseluruhan proses dialog dan diskusi pada akhirnya berhasil melahirkan Bandung Charter of a Human Rights City (Piagam Kota HAM Bandung) yang diluncurkan bertepatan dengan peringatan Hari HAM Sedunia 2015.32 Piagam ini terdiri dari lima bab yang memuat hak dan kewajiban pemerintah kota, warga, maupun stakeholder lainnya dalam menghormati, melindungi, dan memenuhi hak-hak warga kota Bandung. Piagam juga mencantumkan mekanisme pemenuhan hak, remediasi, serta amandemen terhadap piagam, yang menitikberatkan pada keterlibatan warga kota Bandung dalam prosesnya. ${ }^{33}$ Menurut salah satu informan,

\begin{abstract}
"...Prinsipnya bagus, ada transparan, nondiscrimination, stakeholder participation, harus semua pemegang hak atas kota harus ikut. Kita datangkan waktu itu sampai penyandang disabilitas, kepolisian, TNI, itu definisi Kota HAM yang kita mau ada di Piagam Kota HAM Bandung. Ada poin yang mau dipenuhi (the most important rights/hakhak yang harus dipenuhi di Kota Bandung). Maksud saya, ada hak rakyat Bandung dan kewajiban pemerintah kota Bandung. Di bagian akhir, ada bagaimana pengimplementasian dari piagam tersebut, jadi ga di atas kertas aja." ${ }^{34}$
\end{abstract}

Proses pembentukan piagam ini, menurut salah satu informan, merujuk kepada Resolusi Nomor A/HRC/30/49 tentang Role of Local Government in The Promotion and Protection

31 Hasil Wawancara dengan Susi Dwi Harijanti, Paguyuban Hak Asasi Manusia Universitas Padjadjaran, Bandung 6 Februari 2019

32 Dendi Ramdhani, "Bandung Canangkan Diri Sebagai Kota Ramah HAM," KOMPAS.Com, last modified 2015, accessed May 8, 2019, https://regional.kompas.com/ $\mathrm{read} / 2015 / 12 / 11 / 11112941 /$ Bandung.Canangkan.Diri.sebagai. Kota.Ramah.HAM.

33 Bandung Charter of a Human Rights City (Indonesia, 2015), http://fihrrst.org/images/file/1482922541-Bandung Charter_of_a_Human_Rights_City.pdf.

34 Hasil Wawancara dengan Bahtiar Manurung, Foundation for International Human Rights Reporting Standard (FIHRRST), Jakarta, Februari 2019 of Human Rights yang diadopsi pada sesi ketigabelas pertemuan Human Rights Council (HRC). Resolusi HRC ini juga salah satunya mengambil konsep human rights in the city, di mana pemahaman pemenuhan HAM tidak dapat lagi semata-mata hanya ada di tingkat nasional, tetapi turun ke tingkat pemerintah kabupaten/kota.

Bagaimanapun, di sisi lain, informan juga mengutarakan kekecewaannya terhadap pemerintah kota Bandung, dalam hal ini, para birokrat dan Dewan Perwakilan Rakyat Daerah (DPRD) kota Bandung. Birokrasi yang diharapkan dapat menjadi motor penggerak dalam pemenuhan HAM, justru tidak terlalu paham dengan isu-isu HAM.
“...karena paradigma mereka tentang HAM itu menyedihkan. Jadi bagaimana kita bisa melakukan pemenuhan, apabila paradigma HAM belum sesuai. Kenapa? Karena yang di mata mereka [birokrat, pen.] HAM itu urusannya dengan HAM politik, seperti demo, kebebasan berbicara, padahal HAM juga berbicara tentang ekonomi, sosial dan budaya. Tidak ada paradigma yang seperti itu. [...] Pada waktu FGD, OPD banyak yang tidak datang, kami tidak begitu happy dengan kondisi ini. [...] Ketika saya bertemu dengan RK [Walikota Bandung, pen.] beberapa tahun lalu, setelah piagam ini, saya tanyakan tentang kelanjutan Piagam, beliau saat ini mengatakan di DPRD masih belum bisa. [...] Sebenarnya banyak yang menanyakan kelanjutan dari piagam ini, dari sisi masyarakat, tapi tidak dari level pemerintah." 35

Dua contoh kebijakan hak asasi manusia di atas yakni Penghargaan Kabupaten/Kota Peduli HAM dan Deklarasi HAM Bandung, menunjukkan beberapa indikasi. Pertama, penghargaan kabupaten/kota peduli HAM sebagai suatu kebijakan publik yang bersifat topdown, mendapat dukungan penuh dari kalangan pemerintah. Dari sisi masyarakat, bagaimanapun, kebijakan tersebut tidak mendapatkan legitimasi yang cukup. Kriteria penerima penghargaan yang ditentukan secara top-down tidak membuka ruang bagi partisipasi komunitas masyarakat lokal dalam menentukan isu-isu prioritas yang sesuai dengan karakteristik daerah. Sehingga, terjadi kesenjangan antara kebijakan yang diambil dengan harapan warga, membuat predikat Bandung sebagai kota peduli HAM menjadi tidak relevan di mata masyarakat. Kedua, Deklarasi HAM Bandung sebagai suatu kebijakan publik yang

35 Hasil Wawancara dengan Susi Dwi Harijanti, Paguyuban Hak Asasi Manusia Universitas Padjadjaran, Bandung 6 Februari 2019 
bersifat bottom-up menyediakan ruang partisipasi seluas-luasnya bagi komunitas masyarakat lokal. Hal tersebut berhasil mengakomodasi harapan dan tuntutan warga Bandung akan pemenuhan dan pelindungan hak asasi manusia yang dibutuhkan melalui adanya penentuan isu-isu prioritas dalam pembentukan Piagam Kota HAM Bandung. Namun, sangat disayangkan, birokrasi dan aparat pemerintahan yang tidak terlibat aktif menjadi faktor penghambat keberhasilan kebijakan Kota HAM Bandung. Tanpa tindak lanjut melalui suatu regulasi daerah, Piagam Kota HAM Bandung tidak memiliki dasar hukum yang cukup untuk dapat benar-benar diimplementasikan.

Dengan demikian, poin penting yang dapat diambil dari kedua contoh kasus di atas adalah, dalam rangka mendorong upaya pelokalan hak asasi manusia di level daerah, diperlukan suatu kebijakan yang mendapatkan legitimasi kuat dari kedua aktor utama komunitas -masyarakat dan pemerintah. Kebijakan tersebut harus mampu mengakomodasi kepentingan masyarakat lokal dan dalam waktu bersamaan, mendapatkan dukungan kuat dari birokrasi serta aparat pemerintahan. Infusi klaim masyarakat terhadap hak-hak yang dimiliki, tidak akan terakomodasi dengan baik apabila aparat pemerintah tidak terlibat aktif dalam proses deliberasi pada tahap perumusan kebijakan. Legitimasi masyarakat atas kebijakan HAM pemerintah, di sisi lain, tidak bisa tercapai apabila masyarakat tidak terlibat aktif dalam perumusan kebijakan oleh pemerintah.

\section{Menggalang Partisipasi Publik dan Kolaborasi Antar Aktor melalui Human Rights-Based Approach}

Pendekatan berbasis HAM (human rightsbased approach) adalah kerangka konseptual dalam rangka proses pembangunan yang secara normatif berasal dari standar HAM internasional dan bertujuan untuk mempromosikan dan melindungi HAM. Pertama kali diinisasi di tingkat internasional melalui Perserikatan Bangsa-Bangsa (PBB), tujuan utama human rights-based approach ialah dalam rangka pengarusutamaan hak asasi manusia ke dalam seluruh aktivitas dan program di dalam seluruh mandat dan kerangka kerja sistem PBB. ${ }^{36}$ Langkah ini kemudian diikuti oleh

36 Harison Citrawan, "Analisis Dampak Hak Asasi Manusia Atas Regulasi: Sebuah Tinjauan Metodologi,” Jurnal HAM 8, no. 1 (2018): 13 . praktik-praktik negara anggota maupun berbagai organisasi non-pemerintah baik lokal maupun internasional, terutama dalam penyelenggaraan pembangunan -human rights-based approach to development. Lebih lanjut, pendekatan berbasis HAM didesain untuk membantu negara dalam menerjemahkan norma dan standar hak asasi manusia yang terdapat dalam instrumen internasional ke dalam konteks nasional hingga lokal. ${ }^{37}$

Fokus dari pendekatan berbasis HAM adalah untuk memberdayakan masyarakat -terutama masyarakat marjinal-selaku pemegang hak (rights holders) dengan mengembangkan kapasitas untuk mengetahui, melaksanakan, melakukan klaim dan menuntut pemulihan atas haknya. Selanjutnya, pendekatan ini juga mengembangkan kapasitas aktor negara -dalam hal ini pemerintah daerahuntuk menghormati, melindungi, dan memenuhi kewajiban hak asasi manusia selaku pengemban tugas (duty bearers). Tak hanya kedua aktor utama tersebut, pendekatan berbasis HAM juga mengembangkan kapasitas aktor non-negara seperti Organisasi Non-Pemerintah (NGO) yang memiliki kewajiban moral, etika maupun sosial untuk mempromosikan dan mengamati hak asasi manusia. ${ }^{38}$

Selain memastikan pembentukan suatu kebijakan sudah menghormati hak asasi manusia, hal yang tak kalah penting yakni memastikan proses yang ditempuh untuk membuat kebijakan juga menguatkan hak asasi manusia itu sendiri. ${ }^{39}$ Pendekatan berbasis HAM menekankan pentingnya pemberdayaan dan partisipasi dalam prosesnya, karena proses tersebut sudah pasti akan menentukan keberhasilan, kemanfaatan dan penerimaan terhadap outcome yang dihasilkan. Salah satu dinamika mendasar dalam pendekatan berbasis HAM adalah, setiap orang diakui sebagai

37 OHCHR, "What Value Does a Human Rights-Based Approach Add to Development?," UN Practitioners' Portal on Human Rights Based Approaches to Programming, accessed May 19, 2019, https://hrbaportal.org/faq/whatvalue-does-a-human-rights-based-approach-add-todevelopment.

38 Government of Canada, "Human Rights Based Approach," last modified 2017, accessed May 19, 2019, https:// international.gc.ca/world-monde/issues_developmentenjeux_developpement/priorities-priorites/human_rightsdroits_personne.aspx?lang=eng.

39 Victorian Equal Opportunity and Human Rights Commission, "From Principle to Practice: Implementing the Human Rights Based Approach in Community Organisations" (2008): 1-31. 
pemegang hak yang harus dilibatkan sebagai aktor kunci dalam proses pembentukan kebijakan dan pengambilan keputusan yang akan memengaruhi keberlangsungan hidupnya. ${ }^{40}$

Pendekatan berbasis HAM, dalam pelaksanaannya memiliki lima prinsip utama yang dikenal dengan akronim PANEL: participation, accountability, non-discrimination and equality, empowerment, dan legality. ${ }^{41}$ Namun, kajian ini akan fokus pada prinsip pertama dalam pendekatan berbasis HAM, yakni partisipasi. Proses yang partisipatif dalam tahap perencanaan dan perumusan kebijakan serta refleksi konsensus antara rights holders dan duty bearers dapat menentukan akuntabilitas dari suatu kebijakan. Partisipasi melibatkan seluruh stakeholders dalam tahap asesmen, pengambilan keputusan dan implementasi kebijakan. Partisipasi harus bersifat aktif, bebas, dan berarti - partisipan harus dapat membentuk dan menentukan proses pengambilan kebijakan, termasuk berkontribusi secara signifikan terhadap pelaksanaan dan pengawasan terhadap kebijakan tersebut. ${ }^{42}$ Dengan melibatkan banyak pihak, tentunya proses yang partisipatif akan membutuhkan waktu dan sumberdaya yang lebih banyak.

\section{Gambar 2}

The Participation Continuum

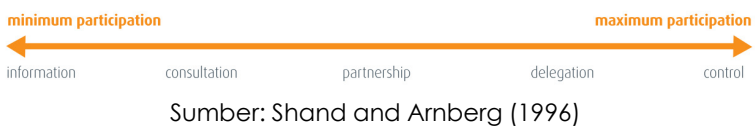

Shand dan Arnberg ${ }^{43}$ mengklasifikasikan partisipasi publik ke dalam lima tingkatan. Pada tingkatan pertama yakni information, bentuk partisipasi berupa memberikan stakeholders akses yang jelas dan tepat atas suatu informasi terkait kebijakan, program, dan layanan. Tingkatan selanjutnya, consultation, adanya proses mencari perspektif stakeholders kunci dalam isu-isu yang memengaruhi secara langsung, sehingga me-

\footnotetext{
40 Ibid.

41 European Network of National Human Rights Institutions, "Applying a Human Rights-Based Approach," last modified 2016, accessed May 19, 2019, http://ennhri.org/Applying-aHuman-Rights-Based-Approach.

42 Victorian Equal Opportunity and Human Rights Commission, "From Principle To Practice: Implementing the Human Rights Based Approach in Community Organisations."

43 Ibid.
}

mungkinkan para stakeholders untuk terlibat dalam proses bisnis organisasi. Tingkat partnership, merupakan tingkatan di mana terjadi dialog jangka panjang antar-stakeholders untuk bekerjasama dalam merumuskan suatu kebijakan. Lalu pada tingkat delegation, adanya pemberian kewenangan kepada stakeholders untuk merumuskan suatu kebijakan dalam kerangka kerja yang sudah disiapkan sebelumnya oleh organisasi. Terakhir pada tingkatan control, organisasi menyediakan cara-cara bagi stakeholders untuk mengambil keputusan secara langsung.

\section{Partisipasi Publik sebagai Jawaban atas Lemahnya Legitimasi Kebijakan Berbasis Hak Asasi Manusia}

Meningkatnya keterlibatan komunitas seringkali disebut sebagai jawaban atas krisis legitimasi serta efektivitas institusi politik. Di sisi lain, terdapat peningkatan kesadaran terkait masalah normatif yang berhubungan dengan mekanisme partisipasi dalam sistem pemerintahan. Terdapat argumentasi bahwa inklusi aktor komunitas yang bersifat selektif dan tidak sistematis, ditambah dengan maraknya pengambilan keputusan yang terfragmentasi dan tidak terpusat, semakin mengikis dasar legitimasi institusi kolektif. ${ }^{44}$ Legitimasi terhadap sistem politik dapat dicapai melalui, salah satunya, kapasitas yang mumpuni dalam merespon keinginan dan kebutuhan (masyarakat).

Scharpf mendefinisikan legitimasi demokratis sebagai konsep dua dimensi: legitimasi melalui input dan legitimasi melalui output. ${ }^{45}$

44 Ibid

45 Fritz W. Scharpf, "Economic Integration, Democracy and the Welfare State," Journal of European Public Policy 4, no. 1 (1997): 18-36.the implication seems to be that economic competition impedes welfare state regulations that impose unequal burdens on capital incomes and mobile business, and that effective welfare state policies depend on the powers of central governments. By analogy, that would suggest a need for the Europeanization of social policy. At the European level, however, welfare state policies are impeded not only by the European democratic de but also by deep-rooted con of economic interest among member states, and by the widely divergent structural characteristics of national welfare states. The article examines the implications of this constellation for democratic legitimacy. In the concluding section, discussion focuses on social policy options that may still be viable at the national level, and on European-level strategies that might be able to reduce economic competition among national welfare states. The current dif culties of democratic welfare states in Europe are often ascribed to economic 'globalization', that is to the world-wide integration of markets for capital, goods and services which has eliminated national 
Legitimasi input, membutuhkan mekanisme atau prosedur yang mengaitkan keputusan politik dengan preferensi masyarakat, sedangkan legitimasi output, membutuhkan mekanisme atau prosedur yang berhasil mencapai tujuan kolektif masyarakat. ${ }^{46}$ Lebih lanjut, Haus dan Heinelt menambahkan legitimasi throughput (proses), yang diartikan legitimasi dapat dicapai melalui prosedur pengambilan keputusan yang transparan, dan pihak pengambil keputusan akuntabel atas keputusan tersebut. ${ }^{47}$ Dengan kata lain, legitimasi input fokus terhadap siapa pihak yang mengambil keputusan, legitimasi output fokus terhadap apa hasil yang dicapai melalui keputusan tersebut, sedangkan legitimasi proses, fokus terhadap proses yang terjadi di antara input dan output; yaitu proses politik yang mengiringi bagaimana terbentuknya suatu kebijakan publik.

Meningkatnya keterlibatan komunitas seringkali disebut sebagai jawaban atas krisis legitimasi serta efektivitas institusi politik. Di sisi lain, terdapat peningkatan kesadaran terkait masalah normatif yang berhubungan dengan mekanisme partisipasi dalam sistem pemerintahan. Terdapat argumentasi bahwa inklusi aktor komunitas yang bersifat selektif dan tidak sistematis, ditambah dengan maraknya pengambilan keputusan yang terfragmentasi dan tidak terpusat, semakin mengikis dasar legitimasi institusi kolektif. ${ }^{48}$ Legitimasi terhadap sistem politik dapat dicapai melalui, salah satunya, kapasitas yang mumpuni dalam merespon keinginan dan kebutuhan (masyarakat).

Sebelum mengidentifikasi relasi antara keterlibatan komunitas dengan legitimasi dalam konteks pelokalan nilai-nilai HAM, diperlukan

control over boundary-crossing economic transactions, and which therefore exposes national producers to worldwide competition. In fact, however, globalization in the strict sense of the word is completely realized only for speculative capital transactions. It is true that in all other areas of economic activity the intensity of international competition has increased as well, and that rms have much greater opportunities to relocate production worldwide. Nevertheless, even under the liberal regimes of the General Agreement on Tariffs and Trade (GATT

46 Mijke Boedeltje and Juul Cornips, "Input and Output Legitimacy in Interactive Governance," NIG Annual Work Conference NIG2-01 (2004): 1-23.

47 Jan Erling Klausen and David Sweeting, "Legitimacy and Community Involvement in Local Governance," in Urban Governance and Democracy, Leadership and Community Involvement, ed. Michael Haus, Hubert Heinelt, and Murray Stewart, 1st ed. (New York: Routledge, 2005), 214-233.

48 Ibid adanya kesamaan cara pandang tentang posisi pembentukan kebijakan ini dalam siklus inputproses-output suatu kebijakan publik. Pelokalan nilai-nilai HAM dilihat sebagai tujuan akhir (output) dari kebijakan hak asasi manusia, sehingga menempatkan kebijakan berbasis HAM sebagai proses dalam rangka mencapai output tersebut.

Legitimasi proses mencakup apa yang dilakukan antara input dan output, yakni proses politik dalam rangka pembentukan suatu kebijakan. Melalui mekanisme yang berbeda dengan dua legitimasi lainnya, legitimasi proses menitikberatkan prinsip efektivitas, akuntabilitas, transparansi, keterbukaan dan inklusivitas. ${ }^{49}$ Legitimasi ini tidak hanya mencakup cara kerja secara keseluruhan, tetapi juga proses intermediasi di mana warganegara yang terorganisir dalam kelompok-kelompok kepentingan memiliki pengaruh langsung dalam pembentukan kebijakan. ${ }^{50}$ Sebagaimana prinsip-prinsip di atas, legitimasi proses dapat dicapai, salah satunya dengan melalui keterlibatan komunitas, di mana keterlibatan tersebut dapat memberikan informasi lebih jauh terhadap stakeholders tentang siapa pembuat kebijakan, kenapa kebijakan tersebut dibentuk, dan apa alternatif lain selain kebijakan tersebut. ${ }^{51}$ Dengan begitu, institusi bisa terlihat transparan dan memungkinkan pengawasan para pembuat kebijakan pada level lokal, lebih jauh, proses ini bisa membuat pimpinan dan pembentuk kebijakan lebih akuntabel.

Pertanyaan pertama terkait relasi antara legitimasi proses dan keterlibatan komunitas adalah siapa yang harus berpartisipasi. Dalam hal inklusivitas, khususnya, merupakan pilihan antara 'participation by all' atau 'participation by some', yang secara lebih spesifik ialah pertanyaan tentang hak untuk berpartisipasi, karena 'all' tidak bisa diharapkan untuk bisa selalu terlibat dalam partisipasi. ${ }^{52}$ Dalam proses penilaian empiris dari proses spesifik pembentukan kebijakan politik, istilah 'full inclusion/inklusi penuh' mengindikasikan absennya pembatasan terhadap partisipasi individu maupun kelompok, bukan

49 Vivien A Schmidt, "Democracy and Legitimacy in the European Union Revisited: Input, Output and 'Throughput ,' Political Studies Association 61 (2013): 2-22. 50 Ibid.

51 Klausen and Sweeting, "Legitimacy and Community Involvement in Local Governance."

52 Ibid. 
sebagai tuntutan partisipasi aktif oleh 'semua'aktor komunitas. Sedangkan dalam network governance, keterlibatan seringkali bersifat terbatas (selective inclusion). Jaringan dibentuk untuk menghasilkan output, sehingga akses ke arena tersebut terbatas hanya kepada aktor komunitas yang menguasai sumber yang berkaitan dengan pemecahan masalah, penerimaan, dan implementasi. ${ }^{53}$ Inklusi terbatas, dalam hal ini diartikan sebagai absennya jaminan prosedural terhadap equal participation rights, bukan absennya partisipasi itu sendiri. ${ }^{54}$ Pertanyaan kedua adalah tentang bagaimana model pengambilan keputusan dalam partisipasi tersebut. Cohen dan Sabel membedakan model pengambilan keputusan deliberative (deliberatif) dan aggregative (agregat). ${ }^{55}$ Dalam model pengambilan keputusan agregat, masyarakat diperlakukan setara, di mana kepentingan masingmasing dianggap memiliki bobot yang sama. Sedangkan dalam model deliberatif, pengambilan keputusan harus melalui proses mencari konsensus, debat terbuka yang mana argumen dipresentasikan dan dibahas di depan publik melalui forum debat publik, dengar pendapat, maupun pertemuan terbuka. ${ }^{56}$

Dua pertanyaan terkait relasi antara legitimasi proses dan keterlibatan komunitas membentuk empat tipologi keterlibatan komunitas: aggregative/full inclusion; aggregative/selective inclusion; deliberative/full inclusion; dan deliberative/selective inclusion. Keempat tipologi ini, memberikan tingkatan legitimasi yang berbeda pada setiap proses pembentukan kebijakan, mulai dari perumusan kebijakan (policy development), pengambilan keputusan (policy decision), dan implementasi kebijakan (policy implementation).

53 Klaus Dieter Wolf, "Contextualizing Normative Standards for Legitimate Governance beyond the State," Participatory Governance (2002): 35-50.

54 Jan Erling Klausen and David Sweeting, "Community Involvement and Legitimation in Urban Governance: An Empirical Analysis," in Legitimacy and Urban Governance, A Cross-National Comparative Study, ed. Hubert Heinelt, David Sweeting, and Panagiotis Getimis, 1st ed. (New York: Routledge, 2006), 191-208.

55 Joshua Cohen and Charles Sabel, "Directly-Deliberative Polyarchy," European Law Journal 3, no. 4 (1997): 313-342. constitutionalism and institutional innovations which may help to open up new dimensions in the search for legitimate European governance structures and their constitutionalisation. Faced with Europe's legitimacy problems, proponents of the European project often react by pointing to the many institutional failings in the (national

56 Klausen and Sweeting, "Community Involvement and Legitimation in Urban Governance: An Empirical Analysis.”
Kebijakan berbasis HAM, sebagaimana umumnya suatu kebijakan publik, memerlukan legitimasi untuk dapat diterima di masyarakat. Bagaimanapun, posisi kebijakan berbasis HAM dalam pelokalan nilai-nilai HAM tak lain adalah sebuah proses, sehingga memerlukan legitimasi lebih lanjut di setiap tahapannya.

Terdapat tiga unsur dalam proses pembuatan kebijakan publik, yakni perumusan kebijakan/ policy development, pengambilan keputusan/ policy decision, dan implementasi kebijakan/ policy implementation. Dalam setiap unsur, tipologi keterlibatan komunitas yang berpengaruh terhadap legitimasi kebijakan pun berbeda.

Pada tahap pertama yakni perumusan kebijakan, legitimasi tertinggi dapat dicapai melalui keterlibatan komunitas dengan proses deliberasi dan inklusi keseluruhan (deliberativel full). Tahap perumusan kebijakan yang melibatkan komunitas secara keseluruhan, dapat dimanfaatkan sebagai media assessment atau belanja masalah dari seluruh aktor komunitas di suatu daerah. Proses deliberasi penuh antar aktor komunitas dalam proses penyusunan Piagam HAM Bandung, merupakan salah satu good practice dalam tahap perumusan kebijakan. Dalam tahapan ini, dapat diidentifikasi pula relasi antara keterlibatan komunitas, legitimasi dan model pendekatan bottom-up. Pendekatan bottom-up menitikberatkan pada pada keterlibatan seluruh komponen aktor komunitas, berpotensi lebih besar untuk mengidentifikasi isu yang harus menjadi prioritas daerah dengan tetap memperhatikan karakteristik lokal. Dengan kata lain, pendekatan bottom-up terbukti efektif mencapai level legitimasi tertinggi dalam merumuskan suatu kebijakan.

Selanjutnya, tahapan kedua yakni pengambilan keputusan, legitimasi tertinggi dapat dicapai melalui keterlibatan komunitas dengan proses deliberasi dan inklusi selektif(deliberative) selective). Seluruh masukan yang berhasil dijaring dalam tahap perumusan kebijakan, menjadi bahan pemerintah selaku decision maker untuk menentukan isu mana yang menjadi prioritas daerah. Terlibatnya aparat pemerintah dalam proses deliberasi pada perumusan kebijakan diharapkan dapat meningkatkan pemahaman organ pemerintah dalam menentukan arah kebijakan dan isu HAM prioritas sesuai dengan klaim dan tuntutan masyarakat. Berdasarkan karakteristik tipologi keterlibatan komunitas di 
atas, dapat diidentifikasi bahwa pendekatan topdown digunakan dalam tahapan pengambilan keputusan, di mana pemerintah selaku pengambil kebijakan menentukan isu prioritas mana yang akan didahulukan untuk diselesaikan dan siapa saja aktor komunitas yang akan dilibatkan dalam pengambilan keputusan.

Pada tahap ketiga yakni implementasi kebijakan, legitimasi tertinggi dapat dicapai melalui keterlibatan komunitas dengan proses deliberasi dan inklusi selektif (deliberative) selective). Tahapan implementasi merupakan titik temu antara tahap perumusan yang bersifat bottom-up dengan tahap pengambilan keputusan yang bersifat top-down. Pertemuan pola bottomup dan top-down dalam tahap implementasi ini dapat memperkecil gap antara kebijakan yang diambil oleh pemerintah dengan hasil akhir yang diharapkan oleh masyarakat. Dalam tahap implementasi pula, berlangsung mekanisme pemantauan dan evaluasi terhadap kebijakan yang diambil. Mengingat tahapan implementasi merupakan area dari administrasi publik, maka ruang partisipasi yang tersedia bagi masyarakat secara otomatis berkurang. ${ }^{57}$ Namun hal tersebut tidak menutup kemungkinan bagi aktor komunitas yang 'terpilih' untuk terlibat dalam tahapan pengambilan keputusan, agar ikut memantau dan mengevaluasi tentang bagaimana kebijakan tersebut diimplementasikan.

Ketiga tahapan dalam proses pembentukan kebijakan hak asasi manusia di atas, bagaimanapun, tidak dapat dilihat sebagai suatu kebijakan yang berdiri sendiri. Dalam kerangka pelokalan nilai-nilai HAM, kebijakan tersebut merupakan bagian dari proses dalam siklus kebijakan publik. Sehingga, legitimasi yang kuat dalam setiap tahapan; perumusan, pengambilan keputusan dan implementasi kebijakan, akan berpengaruh langsung kepada output yang diharapkan: berhasilnya pelokalan nilai-nilai hak asasi manusia di tingkat daerah.

\section{KESIMPULAN}

Ketidaksinkronan antara kebijakan hak asasi manusia pemerintah dengan permasalahan HAM di masyarakat dapat menghambat upaya pelokalan nilai-nilai HAM ke level kota. Ketidaksinkronan

57 Klausen and Sweeting, "Legitimacy and Community Involvement in Local Governance." ini disebabkan oleh kegagalan pemerintah dalam melihat problematika di lapangan, sehingga gagal membentuk suatu kebijakan yang dapat mengakomodasi permasalahan HAM masyarakat. Kegagalan pemerintah tersebut adalah implikasi dari rendahnya partisipasi publik dalam pembentukan kebijakan hak asasi manusia. Sehingga, dapat disimpulkan bahwa relasi antara upaya pelokalan nilai-nilai HAM dan kebijakan berbasis hak asasi manusia adalah, keduanya menekankan pentingnya partisipasi publik dalam keseluruhan prosesnya. Kebijakan berbasis hak asasi manusia, salah satunya, mensyaratkan adanya identifikasi terhadap pemegang hak (rights holder) dan pengemban tugas (duty bearers), untuk selanjutnya memperkuat pemahaman atas tugas dan kapasitas masing-masing aktor. Secara tidak langsung kebijakan berbasis hak asasi manusia juga akan menghadirkan legitimasi yang kuat sebagai implikasi dari keterlibatan masyarakat.

Kebijakan berbasis hak asasi manusia yang sejatinya adalah pertemuan antara pendekatan bottom-up dan top-down atas deliberasi penuh antar aktor kota, dapat memperkuat pemahaman masyarakat sebagai rights holder dan pemerintah selaku duty bearers hak asasi manusia. Dengan demikian, upaya pelokalan hak asasi manusia seharusnya dicapai melalui pembentukan kebijakan berbasis hak asasi manusia.

\section{SARAN}

Berdasarkan simpulan yang telah dijabarkan sebelumnya, saran yang dapat diberikan kepada aktor kota yakni pemerintah dan masyarakat antara lain: pertama, untuk aktor pemerintah selaku decision maker kebijakan hak asasi manusia, mengombinasikan model top-down dan model bottom-up melalui skema partisipasi publik dengan memanfaatkan human rights based approach; kedua, dalam rangka menggalang partisipasi aktif masyarakat, perlu pembentukan maupun penguatan forum komunikasi yang digelar rutin antara pemerintah, organisasi masyarakat sipil, dan aktor komunitas lainnya; ketiga, perlu ada koordinasi dengan aktor komunitas lain dalam rangka meningkatkan pemahaman hak asasi manusia; dan keempat, untuk aktor organisasi masyarakat sipil agar lebih proaktif dalam menyuarakan klaim tuntutan hak asasi manusia di ranah kebijakan publik. 


\section{UCAPAN TERIMA KASIH}

Ucapan terima kasih disampaikan kepada: Tim Penelitian "Institusionalisasi Hak Asasi Manusia di Tingkat Daerah Melalui Penghargaan Kabupaten/Kota Peduli Hak Asasi Manusia", Pusat Penelitian dan Pengembangan HAM, Badan Penelitian dan Pengembangan Hukum dan Hak Asasi Manusia; Informan penelitian dari Kantor Wilayah Kementerian Hukum dan HAM Jawa Barat, Subbagian Hukum dan HAM Pemerintah Kota Bandung, Paguyuban Hak Asasi Manusia Universitas Padjadjaran, Lembaga Bantuan Hukum (LBH) Bandung, Foundation for International Human Rights Reporting Standard (FIHRRST), serta para pihak yang terlibat dalam penelitian ini.

\section{DAFTAR PUSTAKA}

Aguilar, Gaby Oré. "The Local Relevance of Human Rights: A Methodological Approach." The Local Relevance of Human Rights (2011): 109-146.

Baxter, Pamela, and Susan Jack. "The Qualitative Report Qualitative Case Study Methodology: Study Design and Implementation for Novice Researchers." The qualitative reportualitative report 13, no. 2 (2008): 544-559.

Boedeltje, Mijke, and Juul Cornips. "Input and Output Legitimacy in Interactive Governance." NIG Annual Work Conference NIG2-01 (2004): 1-23.

Chueca, Eva Garcia. "Human Rights in the City and the Right to the City." In Global Urban Justice: The Rise of Human Rights Cities, edited by Barbara Oomen, Martha F. Davis, and Michele Grigolo, 103-120. Cambridge University Press, 2016.

Citrawan, Harison. “Analisis Dampak Hak Asasi Manusia Atas Regulasi: Sebuah Tinjauan Metodologi." Jurnal HAM 8, no. 1 (2018): 13.

Cohen, Joshua, and Charles Sabel. "DirectlyDeliberative Polyarchy." European Law Journal 3, no. 4 (1997): 313-342.

Darusman, Marzuki. "Bandung' ${ }^{\mathrm{TM}_{\mathrm{S}}}$ Efforts and Social Justice." The Jakarta Post. Last modified 2015.Accessed May 8, 2019. https:// www.thejakartapost.com/news/2015/04/23/ bandung-s-efforts-and-social-justice.html.

European Network of National Human Rights Institutions. "Applying a Human RightsBased Approach." Last modified 2016. Accessed May 19, 2019. http://ennhri. org/Applying-a-Human-Rights-BasedApproach.

Feyter, Koen De. Localizing Human Rights. Antwerp, 2006.

FIHRRST. "Making the Right Start - Bandung Begins Its Journey as Our Human Rights City." Last modified 2015. Accessed May 8, 2019. http://www.fihrrst.org/making-theright-start-bandung-begins-its-journey-asour-human-rights-city.

Government of Canada. "Human Rights Based Approach." Last modified 2017. Accessed May 19, 2019. https://international.gc.ca/ world-monde/issues_development-enjeux developpement/priorities-priorites/human rights-droits_personne.aspx?lang=eng.

Hatmoko, Widi. "\#SaveXpalaguna: Seniman Tolak Bekas Gedung Palaguna Jadi Mal Dan Hotel." Merahputih.Com. Accessed May 8, 2019. https://merahputih.com/post/ $\mathrm{read} /$ savexpalaguna-seniman-tolak-bekasgedung-palaguna-jadi-mal-dan-hotel.

Human Rights Council. "Role of Local Government in the Promotion and Protection of Human Rights." Vol. A/HRC/30/4, 2015.

INFID. Buku Panduan Kabupaten/Kota HAM. 3rd ed. Vol. 3. Jakarta: INFID, 2018.

- Kertas Kertas Kebijakan: Kabupaten/ Kota HAM Sebagai Strategi Pelaksanaan Hak Asasi Manusia Di Daerah Dan Peran Pemerintah Pusat. Jakarta, n.d.

Klausen, Jan Erling, and David Sweeting. "Community Involvement and Legitimation in Urban Governance: An Empirical Analysis." In Legitimacy and Urban Governance, A Cross-National Comparative Study, edited by Hubert Heinelt, David Sweeting, and Panagiotis Getimis, 191-208. 1st ed. New York: Routledge, 2006.

- "Legitimacy and Community Involvement in Local Governance.” In Urban Governance 
and Democracy, Leadership and Community Involvement, edited by Michael Haus, Hubert Heinelt, and Murray Stewart, 214-233. 1st ed. New York: Routledge, 2005.

OHCHR. "Achievements and Challenges of the Human Rights City Gwangju” 1929 (2011).

"What Value Does a Human RightsBased Approach Add to Development?" UN Practitioners'Portal on Human Rights Based Approaches to Programming. Accessed May 19, 2019. https://hrbaportal.org/faq/whatvalue-does-a-human-rights-based-approachadd-to-development.

Permana, Afif. "Jadi Kota HAM Pertama Di Indonesia, Bandung Ingin Kota Lain Ikut." Last modified 2015. Accessed May 7, $2019 . \quad \mathrm{http}: / /$ bandung.bisnis.com/ $\mathrm{read} / 20150424 / 82444 / 532261 /$ jadi-kotaham-pertama-di-indonesia-bandung-inginkota-lain-ikut.

Ramdhani, Dendi. "Bandung Canangkan Diri Sebagai Kota Ramah HAM." KOMPAS. Com. Last modified 2015. Accessed May 8, 2019. https://regional.kompas.com/read/ 2015 / $12 / 11 / 11112941$ / Bandung. Canangkan.Diri.sebagai.Kota.Ramah.HAM.

Ray, Ranita. "Challenges in Localizing Global Human Rights." Societies Without Borders 7, no. 1 (2012): 29-51.

Scharpf, Fritz W. "Economic Integration, Democracy and the Welfare State." Journal of European Public Policy 4, no. 1 (1997): 18-36.

Schmidt, Vivien A. "Democracy and Legitimacy in the European Union Revisited: Input, Output and 'Throughput."' Political Studies Association 61 (2013): 2-22.

Vandenbogaerde, Arne. "Localizing the Human Rights Council: A Case Study of the Declaration on the Rights of Peasants." Journal of Human Rights 16, no. 2 (2017): 220-241.

Victorian Equal Opportunity and Human Rights Commission. "From Principle to Practice: Implementing the Human Rights Based Approach in Community Organisations" (2008): 1-31.
Wolf, Klaus Dieter. "Contextualizing Normative Standards for Legitimate Governance beyond the State." Participatory Governance (2002): $35-50$.

Bandung Charter of a Human Rights City. Indonesia, 2015. http://fihrrst.org/images/ file/1482922541-Bandung_Charter_of_a Human_Rights_City.pdf.

European Charter for Safeguarding Human Rights in the City. Saint Denis, 2002. 